\title{
The first occurrence of Phlebopteris dunkeri and P. woodwardii (Matoniaceae) from the middle Jurassic of Iran
}

\author{
Mohammad Taghi Badihagh ${ }^{1^{*}}$ and Dieter Uhl $^{2}$
}

\begin{abstract}
The coal horizons of the Middle Jurassic Hojedk Formation of East-Central Iran are fossiliferous, bearing numerous well-preserved fossil plants, comparable to the Shemshak Group/Formation in the Alborz Mountains in Northern Iran. Here we present two recently discovered fossil taxa from the Middle Jurassic Hojedk Formation of the Tabas Block (Central Iran). Based on their distinct morphologies, impression/compression specimens can be assigned to Phlebopteris dunkeri (Schenk) Schenk (Palaeontographica 23: 157-163, 1875) and P. woodwardii Leckenby (Quarterly Journal of the Geological Society 20 (1-2): 74-82, 1864), belonging to Matoniaceae. This is the first record of these two taxa in Iran. Taxa belonging to Equisetaceae, Marattiaceae, Dipteridaceae, Schizaeaceae, Dicksoniaceae, Caytoniales, Bennettitales, Cycadales and Podozamitaceae were observed as accompanying taxa in the studied section. Ecology comparison of the Hojedk Formation plant fossils with the extant relatives of the fossil plant taxa occurring in these deposits indicates accumulation of the host strata under a moist warm (tropical to subtropical) climate during the Middle Jurassic.
\end{abstract}

Keywords: Matoniaceae, Phlebopteris, Middle Jurassic, Palaeoecology, Central Iran

\section{Introduction}

The Triassic-Jurassic sedimentary successions of Iran are well known for their wealth of fossil plants and many palaeobotanists have studied these plant-bearing deposits. Many researchers have studied the plant fossils of the Iranian Mesozoic (especially the Triassic and the Jurassic) because it is one of the most significant floras of this age in the world. The study on these floras started with Göppert (1861), regarding the Tash Area, followed by Stur (1886) regarding the Ab-e-Yek Area, and Schenk (1887) regarding the Hiv region. Subsequently, a large number of additional Mesozoic floras in Alborz Mountains and in Central Iran (Fig. 1) has been discovered and studied, reflected by the works of Krasser (1891), Zeiller (1905), Boureau et al. (1950), Kilpper (1964, 1968, 1975), Lorenz (1964), Barnard (1967a, 1967b, 1968), Alavi and Barale (1970), Fakhr (1975), Barnard and Miller (1976), Sadovnikov (1976, 1989), Corsin and Stampfli (1977), Schweitzer (1977,

\footnotetext{
* Correspondence: mtbadihagh@ut.ac.ir

${ }^{1}$ School of Geology, Faculty of Science, University of Tehran, Tehran, Iran Full list of author information is available at the end of the article
}

1978); and then, studies of Boersma and Van Konijnenburg-van Cittert (1991), Schweitzer and Kirchner (1995, 1996, 1998, 2003), Schweitzer et al. (1997, 2000, 2009), Mirzaei-Ataabadi et al. (2005), Vaez-Javadi and Mirzaei-Ataabadi (2006), Saadat-Nejad et al. (2010), and Popa et al. (2012), recently.

The Hojedk Formation, included into the Shemshak Group, overlies the marine sediments of the early Bajocian Badamu Formation, following a marine regression, and is overlain by the Parvadeh Formation. The formation consists of arcosic-quartzitic sandstones and green to grey shales with coal-bearing intervals (Fürsich et al. 2009) (Fig. 2). The coal horizons of the Middle Jurassic Hojedk Formation of East-Central Iran are fossiliferous, comparable to the Shemshak Group/Formation in the Alborz Mountains in North Iran. The Hojedk Formation is known for containing diverse assemblages of plant fossils (e.g., Vassiliev 1984; Poole and Mirzaei-Ataabadi 2005; Ameri et al. 2014). It is Bajocian-Bathonian in age, based on ammonites (e.g., Seyed-Emami et al. 2004) and plant fossils (e.g., Vassiliev 1984; Schweitzer and Kirchner 1996, 1998; Poole and Mirzaei-Ataabadi 2005; Ameri 
et al. 2014). Additionally, the plant-bearing successions of this formation were dated palynologically as Middle Jurassic (Arjang 1975).

This paper discusses two taxa, which are reported for the first time from the Middle Jurassic Hojedk Formation of the Tabas Block, Central Iran (Fig. 1) and provides their description and a short review of the palaeoecology of their families and families of associated taxa in the Middle Jurassic deposits of the source area. This is the first report of Phlebopteris dunkeri and $P$. woodwardii (Matoniaceae) from Iran despite the fact that previous palaeobotanical studies on Iranian plant-bearing formations already recognized diverse floras from numerous localities.

\section{Materials and methods}

The specimens studied here, come from exploration well no. 233, which is located at $60 \mathrm{~km}$ southwest of Tabas City in South Kuchak-Ali Area, South Khorasan Province (GPS: $33^{\circ} 15^{\prime} 39^{\prime \prime} \mathrm{N}, 56^{\circ} 22^{\prime} 44^{\prime \prime} \mathrm{E}$; Fig. 1). Impression/compression fossils of these taxa occur in a grey shale deposit from $204 \mathrm{~m}$ and $301 \mathrm{~m}$ above the base of the Hojedk Formation.

Due to the fact that the studied material originates from a well, the numbering of specimens is done from the top of the succession to the base (Fig. 2). The specimens are well-preserved, since they were obtained from a considerable depth below the surface and are not affected by weathering or other destructive factors. Attempts to extract cuticles from the samples were unsuccessful, probably due to the metamorphosis (high pressure and temperature). Specimens were photographed with a Canon EOS600D digital camera. The samples of Phlebopteris dunkeri and P. woodwardii are stored in the collection of the University of Tehran, Iran, with the inventory numbers MBH319/204 (Phlebopteris dunkeri), MBH390/301, MBH391/301, MBH392/301, MBH393/301, MBH395/301, MBH402/301 (Phlebopteris woodwardii).

In total 495 core samples were documented from strata assigned to the Hojedk Formation; most of the taxa from this core belong to easily recognizable genera of Equisetaceae (Annulariopsis Zeiller; Equisetites Sternberg), Marattiaceae (Marattiopsis Schimper), Osmundaceae (Todites Seward emend. Harris), Dipteridaceae (Clathropteris Brongniart; Dictyophyllum Lindley and Hutton), Schizaeaceae (Klukia Raciborski, emend. Harris), Dicksoniaceae (Ferizianopteris Fakhr; Dicksonia L'Heritier; Coniopteris Brongniart), Incertae sedis (Cladophlebis Brongniart; Spiropteris sp.), Caytoniales (Sagenopteris Presl, emend. Harris), Bennettitales (Pterophyllum Brongniart; Anomozamites (Schimper) emend. Harris; Ptilophyllum Morris), Cycadales (Nilssonia Brongniart), Cupressaceae (Elatides Heer; Elatocladus Halle), Incertae sedis (Podozamites Braun), accompanying the recently discovered Phlebopteris woodwardii Leckenby and $P$. dunkeri (Schenk) Schenk studied in this paper.

\section{Systematic palaeobotany \\ Division: Filicophyta (Pteridophyta) \\ Class: Filicopsida \\ Order: Filicales \\ Family: Matoniaceae}

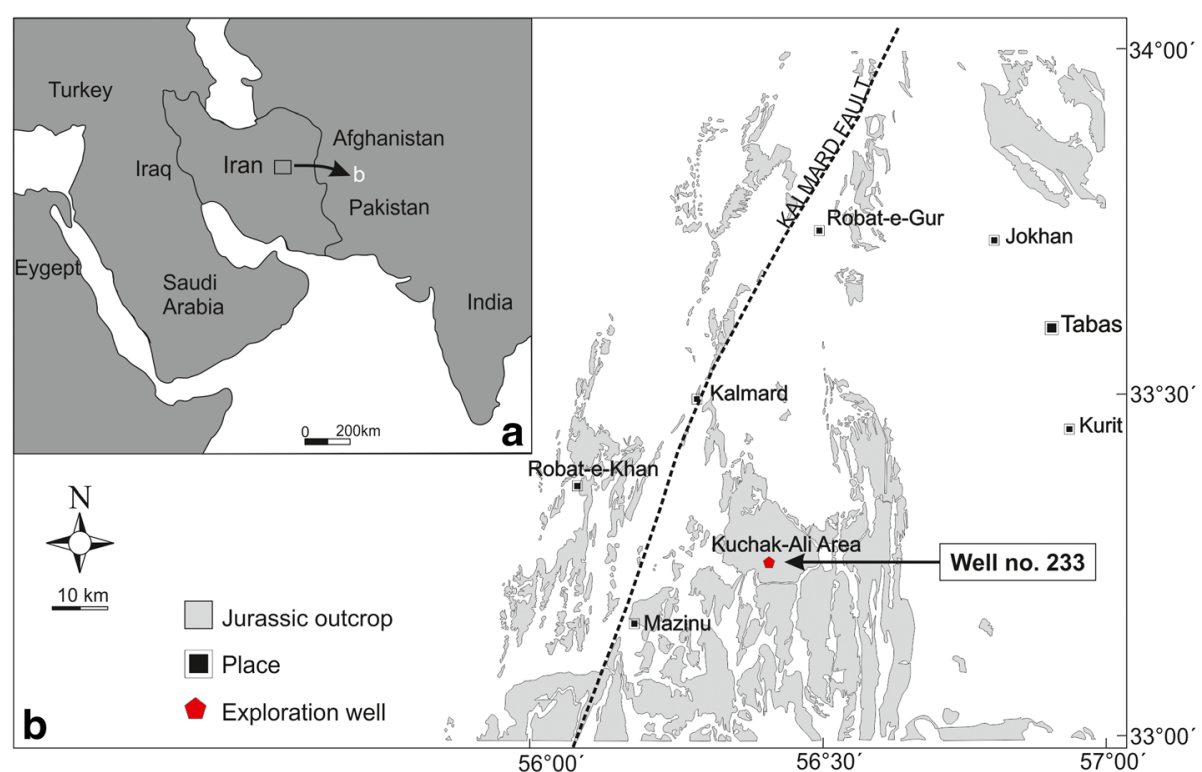

Fig. 1 Simplified map showing the position of $\mathbf{a}$ - the study area, and $\mathbf{b}$ - the exploration well no. 233 of the Hojedk Formation in South Kuchak-Ali Area, Tabas Block, Central Iran 


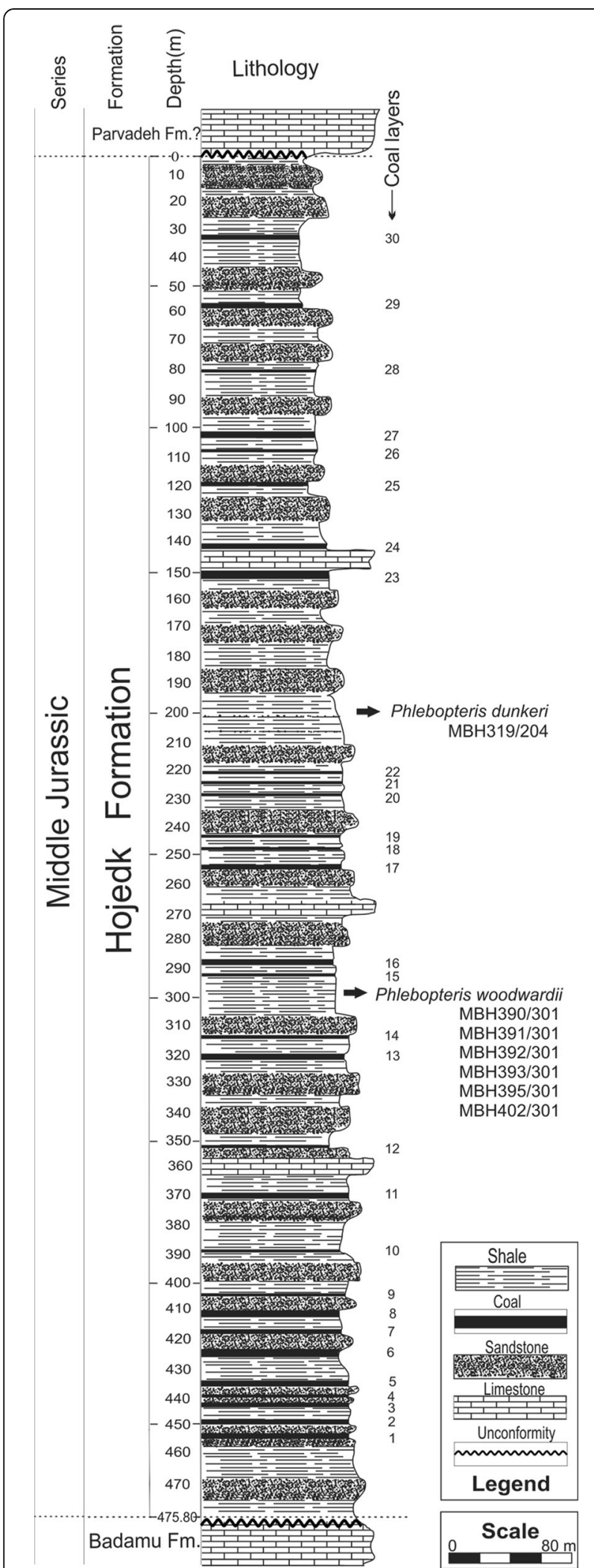

Fig. 2 Lithostratigraphic column and occurrence of Phlebopteris dunkeri and $P$. woodwardii through the succession of the Hojedk Formation in the exploration well no. 233, in South Kuchak-Ali Area, Tabas Block, Central Iran
Genus: Phlebopteris Brongniart 1836

Type species: Phlebopteris polypodioides Brongniart 1836 The genus Phlebopteris was established by Brongniart (1836) with the type species $P$. polypodioides. It is used for fern remains of matoniaceous affinity with pinna exhibiting short or long pinnules with decurrent or non-decurrent base; midrib often reaching the apex; secondary veins dichotomously branched, with or without forming a reticulate venation; circular sori lacking indusium; sori with five to six annulate sporangia annulus; trilete, subtriangular, tetrahedral or round spores.

The genus, which was almost globally distributed during the Jurassic, is considered as the oldest representative of the Matoniaceae, with a geographical focus on the Northern Hemisphere (e.g., Van Konijnenburg-van Cittert 1993; Schweitzer et al. 2009). Hirmer and Hörhammer (1936) synonymized the genus Laccopteris, erected by Presl (1838; in Sternberg) with the type species L. elegans., with Phlebopteris.

Phlebopteris dunkeri (Schenk) Schenk 1875.

(pl. 1, figs. a, b)

1871 Laccopteris dunkeri Schenk; p. 219; figs. 3-5.

1875 Microdictyon dunkeri (Schenk) Schenk; p. 161, pl. 27, fig. 10; pl. 28, fig. 11a-11d.

1961 Phlebopteris dunkeri (Schenk) Schenk: Harris; p. 109; text-fig. 36A-36C.

1984 Phlebopteris dunkeri (Schenk) Schenk: Van der Burg \& Van Konijnenburg-van Cittert; p. 361; pls. I, 2-4; fig. 4.

2016 Phlebopteris dunkeri (Schenk) Schenk: Kustatscher et al.; pl. 1; figs.6-7.

Description A partially, ill-preserved fertile pinnule, $45 \mathrm{~mm}$ long, $10 \mathrm{~mm}$ wide. The substance of the pinnule is thin. This small fragment has a distinct venation. The midrib is approximately $1 \mathrm{~mm}$ wide, straight and depressed adaxially (abaxially prominent). The secondary veins are attached to the midrib (primary vein) at right angles and arise at intervals of approximately $2 \mathrm{~mm}$ along the midrib. The secondary veins are forking at about halfway between the midrib and the margin. After branching, each secondary vein is attached to the adjacent secondary veins, resulting in an arc. The tertiary veins on top of the arc run towards the pinnule margin and are branched twice and produce a slightly elongated network. In the center of the secondary arcs, small convergent veins are inserted at intervals between the secondary veins, which supplied the placenta impression. No sori have been observed on the lamina in the Iranian specimens; just placenta impressions are visible, occurring at half the distance between the midvein and the pinnule margin. 
Remarks Phlebopteris dunkeri (Schenk) Schenk 1875 is represented by small fragments with prominent reticulate venation and often these remains exhibit a fusain-like preservation (e.g., Harris 1961; Van der Burgh and Van Konijnenburg-van Cittert 1984; Van Konijnenburg-van Cittert and Van der Burgh 1996; Kustatscher et al. 2016). Schenk (1871) described this species as Laccopteris dunkeri, later transferred to L. dunkeri to Microdictyon dunkeri by Schenk (1875), using the denomination Phlebopteris dunkeri on plates (Harris 1961).

This fern is almost always showing a reticulate venation (e.g., Harris 1961; Van der Burgh and Van Konijnenburg-van Cittert 1984; Van Konijnenburg-van Cittert and Van der Burgh 1996; Kustatscher et al. 2016). The new isolated fragment from Iran is not fusinitic as in other cases, but can be assigned to Phlebopteris dunkeri (Schenk) Schenk 1875 based on the characteristic venation and on the position of the sori (e.g., Schenk's pl. 1, figs. 1, 2; and also, Harris 1961; Van der Burgh and Van Konijnenburg-van Cittert 1984). This taxon resembles Phlebopteris woodwardii Leckenby 1864 but differs from it by the more complex venation, which is isodiametric or slightly elongated in P. dunkeri and elongated in P. woodwardii and by the position of the sori (Harris 1961), which are nearer to the midrib in $P$. woodwardii than in $P$. dunkeri. In addition, several small veins are inside the arc of P. dunkeri forming irregular meshes, but in Phlebopteris woodwardii only one short vein arises and runs beneath the sorus. This difference also plays a crucial rule in distinguishing between both taxa. Our material has therefore been attributed to Phlebopteris dunkeri mostly on the basis of its venation inside the vein arc.

Phlebopteris dunkeri has been reported from the Middle Jurassic to the Early Cretaceous strata (Van Konijnenburg-van Cittert 1993) from various localities in Europe (such as, Germany: Schenk 1871, 1875; Yorkshire in England, Scotland, France, Poland: Harris 1961, Van der Burgh and Van Konijnenburg-van Cittert 1984; Sardinia in Italy: Kustatscher et al. 2016). The Phlebopteris dunkeri specimens published by Kustatscher et al. (2016; p. 151; pl. 1; Fig. 6) come without a detailed description, but the material exhibits an oblique insertion of pinnules and midribs to the rachis.

Material one specimen: MBH319/204.

Phlebopteris woodwardii Leckenby 1864.

(pl. 2, figs. a-e; figs. 3-5)

1864 Phlebopteris woodwardii Leckenby; p. 81; pl. 8; fig. 6. 1900 Laccopteris woodwardii Leckenby: Seward; p. 77 (Seward, 1900).

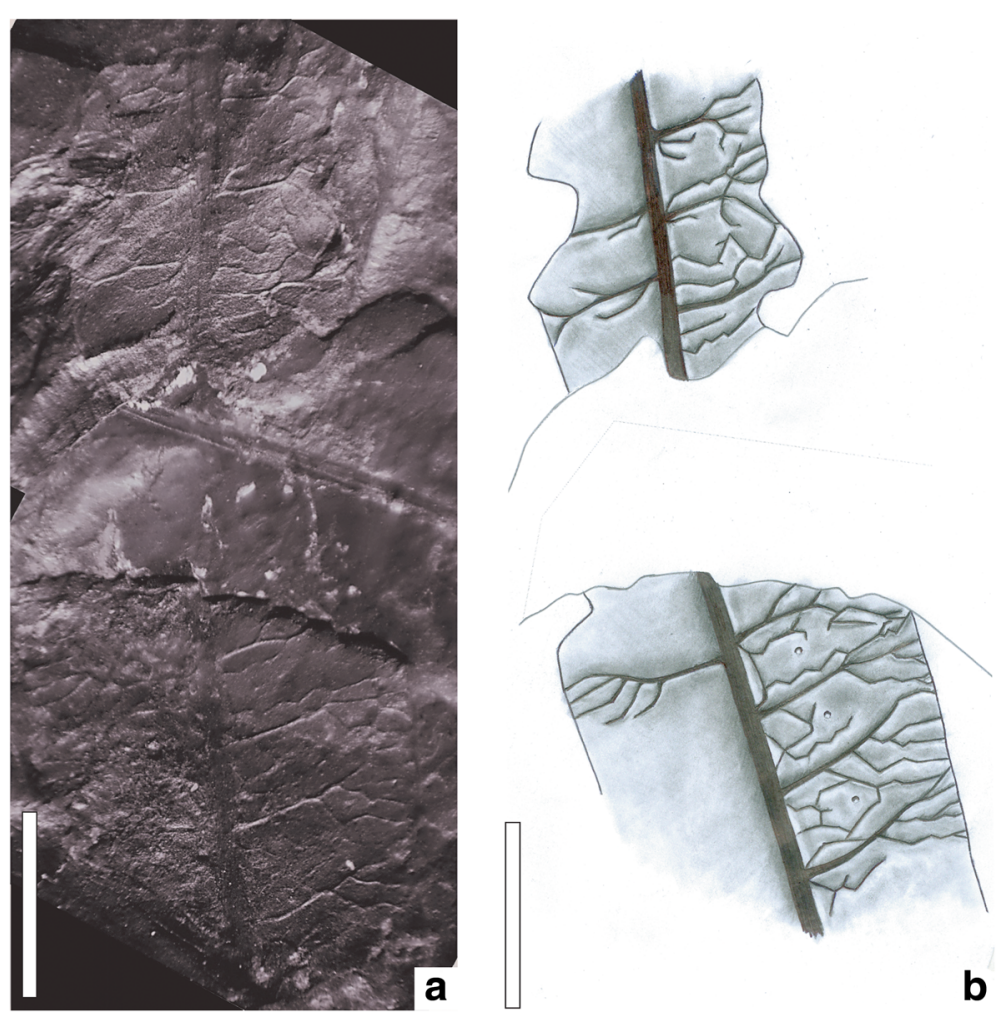

Plate 1 Fertile pinnule of Phlebopteris dunkeri (Schenk) Schenk 1875. a - Adaxial surface; b - Sketch of Phlebopteris dunkeri showing venation system and position of placenta. Leaf fragment from sample MBH319/204. Scale bar: 5 mm 

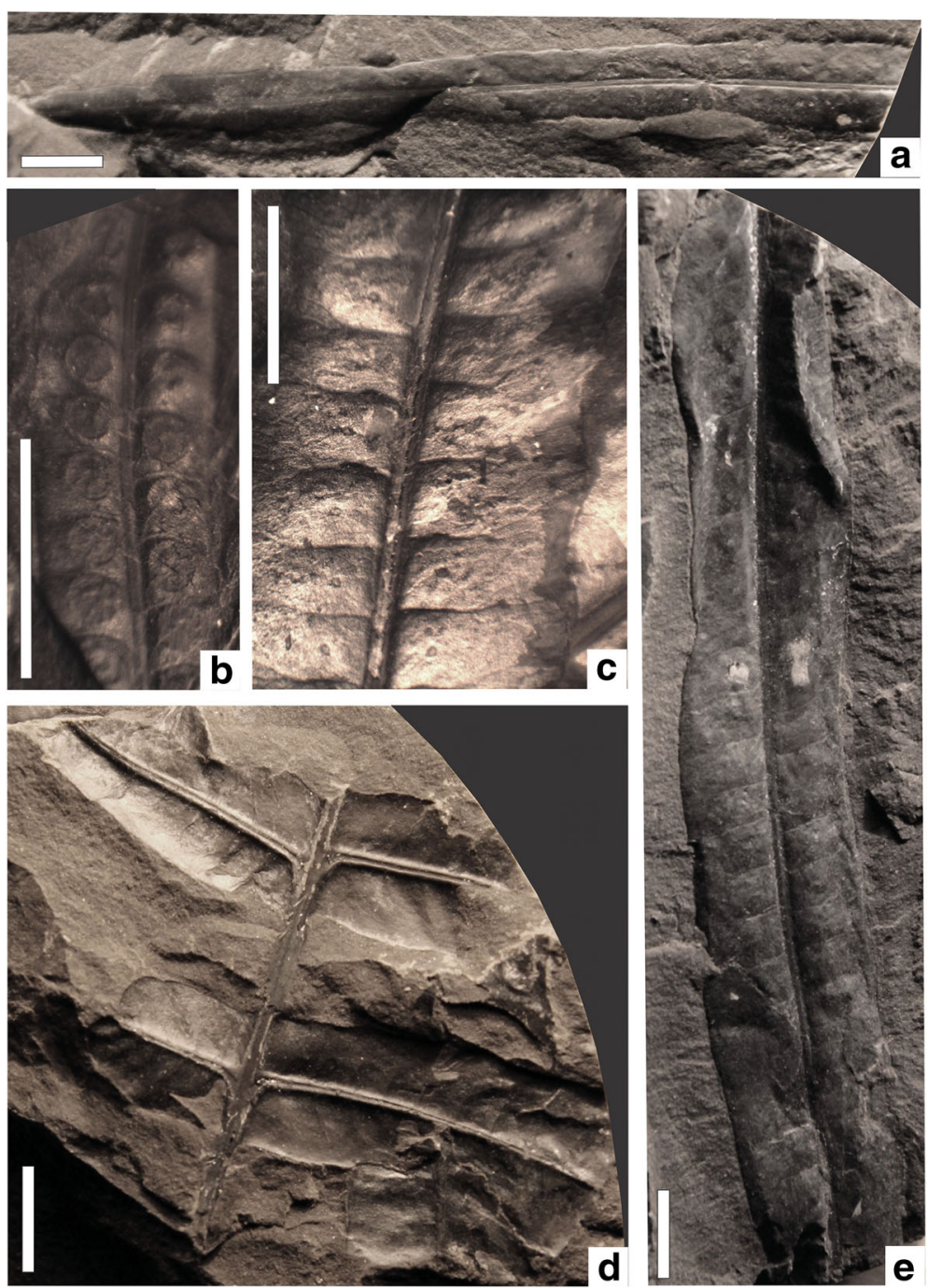

Plate 2 Leaf fragments of Phlebopteris woodwardii Leckenby, 1864. a - Upper part of a fertile pinnule without apex, leaf fragment from sample MBH402/ 301; b - Fertile pinnule showing sori and their positions, leaf fragment from sample MBH395/301; c - Fertile pinnule showing the arc and elongated veins net, leaf fragment from sample MBH390/301; $\mathbf{d}$ - Sterile pinna showing the perpendicular insertion of pinnules, leaf fragment from sample MBH392/301; e - Sterile pinnule showing the waved margin as the result of preservation, leaf fragment from sample MBH391/301. Scale bar: 5 mm

1961 Phlebopteris woodwardii Leckenby: Harris; p. 106; text-fig. 35.

1997 Phlebopteris woodwardii Leckenby: Popa; p. 141; figs. 15-18; pl. 6; fig. 6.

1999 Phlebopteris woodwardii Leckenby: Popa \& Van Konijnenburg-van Cittert; p. 181; pl. 1; figs. 1-6; pl. 2, fig. 4. 2003 Phlebopteris woodwardii Leckenby: Cleal \& Rees; p. 743; pl. 1, figs. 2-3.

Description In sterile fronds the rachis is approximately $3 \mathrm{~mm}$ wide, with longitudinal striations, which continue along the midrib. The pinnules are linear-lanceolate, symmetrical and oppositely attached to the upper surface of the rachis at right angles. The lower and upper margins of the pinnules are weakly decurrent (Fig. 3). The pinnules are up to $60 \mathrm{~mm}$ long and their width is about $11 \mathrm{~mm}$ at the base and tapering to $2 \mathrm{~mm}$ at the apex; their margins are entire with parallel sides. Some pinnule margins are undulate, but this might be the result of preservation. The pinnule apices are not preserved. Adjacent pinnules are parallel and separated from each other by a narrow interval close to $5 \mathrm{~mm}$. The midrib is attached perpendicular to the rachis. In sterile pinnules the midrib is straight, stout and prominent on abaxial surface and is about $2 \mathrm{~mm}$ wide (Fig. 3 ).

The midrib of neighboring pinnules are inserted at intervals between 9 to $11 \mathrm{~mm}$. Secondary veins are opposite to subopposite, arising from the midrib at right angles, 1 to $2 \mathrm{~mm}$ apart in sterile pinnules and 2 to 2.5 $\mathrm{mm}$ in fertile pinnules. These distances indicate that the frequency of the secondary veins in sterile pinnules is higher than in fertile pinnules; this might be the 


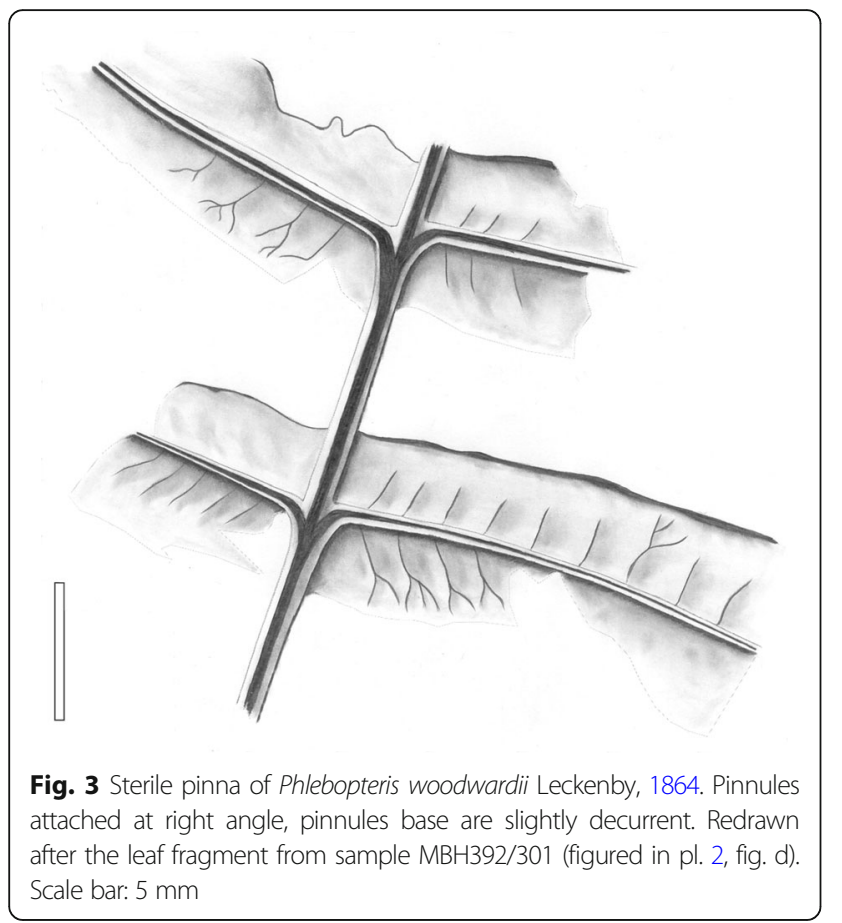

result of the presence of sori during the maturation. The secondary veins divide at about halfway between the midrib and the pinnule margin, finally each branch running forward and backward, becoming an arc. The tertiary veins arise from the top of the arc, simple or forking once or twice, meeting the pinnule margin and forming (non-anastomosed) elongated meshes with four parallel veins (Fig. 4). Both, sterile and fertile pinnules exhibit a small and short vein which emerges near the midrib. In fertile pinnules, this short vein touches the sori, no other veins occurring inside the arc (Figs. 4, 5). One fertile fragment-bearing circular sori of about $0.9-1 \mathrm{~mm}$ diameter, without indusium, arranged in two rows very close (less than $0.5 \mathrm{~mm}$ ) to the midrib, might also belong to this species (Figs. 4, 5). They are flanked by an arc. The number of sporangia in each sorus is 5 to 6 (Fig. 5).

Remarks Givulescu and Popa (1998) defined the genus Aninopteris from the Early Jurassic of Romania which possesses pinnules with contracted base and large pinnules, separating it from Phlebopteris (see Givulescu and Popa 1998; Popa and Van Konijnenburg-van Cittert 1999). Phlebopteris (Aninopteris) formosa var. persica. from the Middle Jurassic of Mazino coalmine, East-Central Iran was described by Mirzaei-Ataabadi et al. (2005), differing from the Romanian material in a higher number of sporangia and in less-branched secondary veins. Schweitzer et al. (2009, p. 36) argued that a constricted pinnules base is not enough to create a new genus, as both states can be seen within a single genus of living ferns. Thus, based on the Iranian material and the Romanian material, Aninopteris was rejected and combined by them as Phlebopteris formosa. We agree with Schweitzer et al. (2009) that constricted base is not providing enough reason to create a new fern genus. Characters of the material documented by Schweitzer et al. (2009) are closely related to the characteristics of both Phlebopteris formosa and P. woodwardii (Table 1). Phlebopteris woodwardii is very similar to $P$. formosa but differs from it by the characteristics of pinnule base, which is auricular in P. formosa (Givulescu and Popa 1998). Also, the secondary veins in Phlebopteris formosa are tree-like and anastomosed but the tertiary veins in $P$. woodwardii form and elongated net. The basal

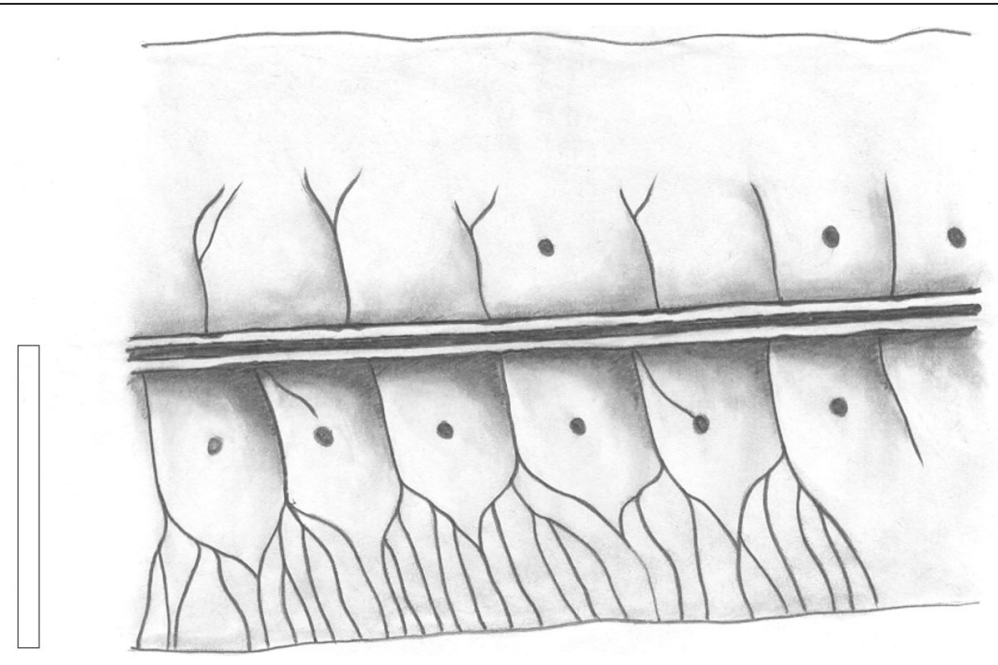

Fig. 4 Fertile pinnule of Phlebopteris woodwardii Leckenby, 1864. Secondary veins attached at right angle. Redrawn after the leaf fragment from sample MBH390/301 (figured in pl. 2, fig. c). Scale bar: $5 \mathrm{~mm}$ 


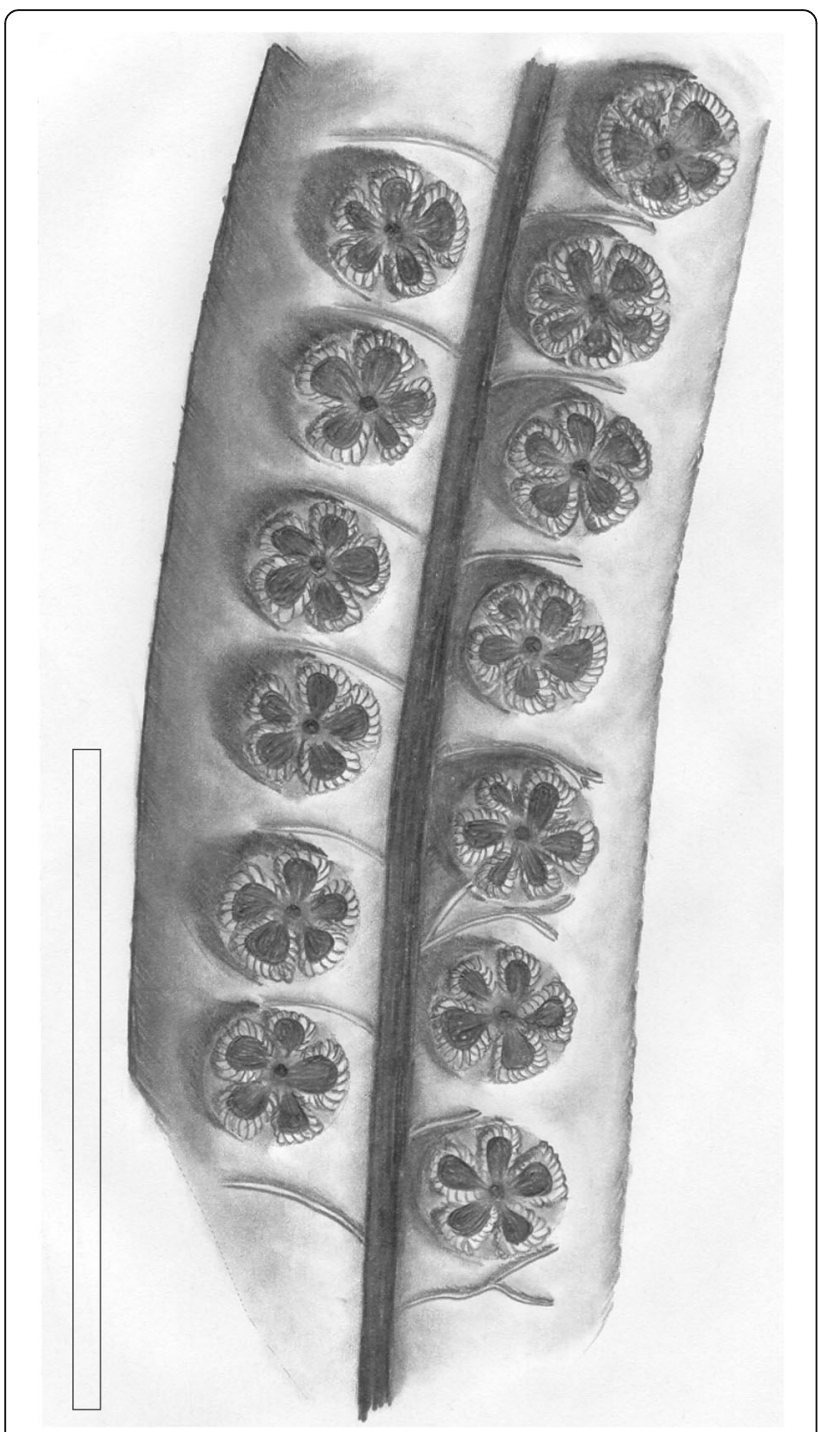

Fig. 5 - Position of sori in a fertile pinnule of Phlebopteris woodwardii Leckenby, 1864. Redrawn after the leaf fragment from sample MBH390/ 301 (figured in pl. 2, fig. b). Scale bar: $5 \mathrm{~mm}$

constriction is the most characteristic and unique character to distinguish Phlebopteris formosa from other species of Phlebopteris. This has, however, never been observed in the Iranian material collected by Schweitzer et al. (2009). Additionally, the Romanian specimens lack a small and short vein at the junction between the midrib and the secondary veins (Givulescu and Popa 1998), while the Iranian specimens have this small and short vein (Schweitzer et al. 2009). Harris (1961. p. 107) considered this short vein as one of the characteristics of Phlebopteris woodwardii. Therefore, there is an ambiguity concerning the determination of Schweitzer et al. (2009), because without the presence of a pinnule base it is impossible to separate these two taxa. Popa and Van Konijnenburg-van Cittert (1999) were the first to describe the spores of Phlebopteris woodwardii. They extracted in situ spores from fertile pinnules of Phlebopteris woodwardii which were collected from the Early Jurassic of the Getic Nappe, Ponor Quarry, Resita Basin (Banat), Romania (Additional file 1: Table S2).

Phlebopteris woodwardii is distinguished from $P$. polypodioides Brongniart 1836 by the network of the primary veins inside the arc. The Tabas specimens can distinctly be assigned to Phlebopteris woodwardii Leckenby 1864 due to the position of the sori close to the midrib and a tiny, short vein occurring at the angle between the midrib and primary vein.

Phlebopteris woodwardii differs from P. angustiloba by narrow rachis, large pinnules, pinnules base and entire margin which is wide in the rachis $P$. angustiloba, pinnules are small, pinnules base are slightly interconnected and margin is slightly wavy. Phlebopteris woodwardii is distinguished from $P$. polypodioides in having linear-lanceolate shape and short vein feeding sori, also, the height of arc in P. woodwardii is larger than the width, contrary to $P$. polypodioides, and the size of sporangia in $P$. woodwardii is smaller than in P. polypodioides. Phlebopteris muensteri differs from $P$. woodwardii by short pinnules, acute insertion angle, large sori which occupied half of the midribmargin distance. By having very long and narrow pinnules with basal web between pinnules, inserted in oblique angle $\left(75-80^{\circ}\right)$ and 4 secondary veins in each millimeter, it is distinguished from Phlebopteris woodwardii. Phlebopteris affinis is distinguished from $P$. woodwardii by having oblique insertion of midrib and anastomosed secondary vein. Phlebopteris tracyi differs from $P$. woodwardii in anastomosed secondary veins with wide polygonal shape and narrow pinnules. Phlebopteris woodwardii is distinguished from P. caucasia by elongated net and bigger pinnules. Arising secondary veins at $45-50^{\circ}$, elongate, falcate, short and slim pinnules in Phlebopteris minutifolius, help to differentiate it from $P$. woodwardii (for a more detailed comparison see Additional file 1: Table S2).

Harris (1961) mentioned that the Yorkshire material is preserved as fusain fragments, while the Stonesfield specimens do not appear to be preserved as fusain (Cleal and Rees 2003). Phlebopteris woodwardii has been reported from the Early Jurassic up to the Early Cretaceous strata from various localities in Europe (e.g., Yorkshire: Harris 1961; Romania: Popa 1997; Oxfordshire: Cleal and Rees 2003).

Material MBH390/301, МВН391/301, МВН392/301, MBH393/301, MBH395/301, MBH402/301.

\section{Palaeoecology}

The Mesozoic was an era of globally warm climate. The presence of thermophilic plant remains from the Arctic and Antarctic regions indicates an absence of polar icecaps and likely a belt of cold climate in this area. 
Table 1 Comparison of documented material from Iran and Romania (Phlebopteris formosa) with material of this study (P. woodwardii)

\begin{tabular}{|c|c|c|c|}
\hline & $\begin{array}{l}\text { Phlebopteris formosa, Iranian } \\
\text { material (Schweitzer et al. 2009) }\end{array}$ & $\begin{array}{l}\text { Phlebopteris formosa, Romanian material } \\
\text { (Givulescu and Popa 1998; Popa and } \\
\text { Van Konijnenburg-van Cittert 1999) }\end{array}$ & $\begin{array}{l}\text { Phlebopteris woodwardii, Iranian } \\
\text { material (this study) }\end{array}$ \\
\hline Rachis & $\begin{array}{l}\text { 6-7 mm, with longitudinal } \\
\text { striation }\end{array}$ & $\begin{array}{l}1.5-8 \mathrm{~mm} \text {, with longitudinal striation or } \\
\text { unornamented }\end{array}$ & $\begin{array}{l}\text { Approximately } 3 \mathrm{~mm} \text {, with longitudinal } \\
\text { striation }\end{array}$ \\
\hline Pinnule insertion, angle & Unknown, perpendicular & Alternate or subopposite, perpendicular & Opposite, perpendicular \\
\hline Pinnule shape & Unknown & Lanceolate & Linear-lanceolate \\
\hline Pinnule base & Missing & Roundly constricted & Slightly decurrent \\
\hline Pinnule margin & Entire & Entire, parallel & Entire, parallel \\
\hline Pinnule apex & Missing & Unknown & Missing \\
\hline Pinnule length & $80 \mathrm{~mm}$, up to $150 \mathrm{~mm}$ & 70-100 mm over & $60 \mathrm{~mm}$ (longest), exceeding $60 \mathrm{~mm}$ \\
\hline Pinnule width & 12 mm (10-14 mm) & $6-9 \mathrm{~mm}$ & 11 mm (basally), 2 mm (apically) \\
\hline Midrib & Strong & Straight, stout & Straight, stout \\
\hline Midrib ornamentation & Unknown & Unornamented & Longitudinal striation \\
\hline Midrib insertion & Unknown & Perpendicular & Perpendicular \\
\hline Midrib width & $1 \mathrm{~mm}$ & $0.5-1.5 \mathrm{~mm}$ & $2 \mathrm{~mm}$ \\
\hline $\begin{array}{l}\text { Distance of adjacent } \\
\text { midribs }\end{array}$ & Unknown & $7-15 \mathrm{~mm}$ & 9-11 mm \\
\hline $\begin{array}{l}\text { Lateral insertion } \\
\text { (secondary vein) }\end{array}$ & $\begin{array}{l}\text { Slightly oblique, opposite } \\
\text { to subopposite }\end{array}$ & $\begin{array}{l}\text { Slightly oblique, } 75-85^{\circ} \text {, opposite } \\
\text { to subopposite }\end{array}$ & Perpendicular, opposite to subopposite \\
\hline $\begin{array}{l}\text { Distance of lateral } \\
\text { veins }\end{array}$ & $2-3 \mathrm{~mm}$ & $1.5-2 \mathrm{~mm}$ & $2-2.5 \mathrm{~mm}$ \\
\hline Dividing & $\begin{array}{l}\text { Halfway up the lamina, tree-like, } \\
\text { without arc, anastomosed }\end{array}$ & $\begin{array}{l}\text { Halfway up the lamina, tree-like, } \\
\text { without arc, narrow net }\end{array}$ & $\begin{array}{l}\text { Lower half or halfway up the lamina, } \\
\text { making arc (height more than width), } \\
\text { elongated net }\end{array}$ \\
\hline Sorus shape & $\begin{array}{l}\text { Circular, supporting by a } \\
\text { short vein }\end{array}$ & $\begin{array}{l}\text { Circular, without supporting by } \\
\text { a short vein }\end{array}$ & Circular, supporting by a short vein \\
\hline Sorus diameter & $1.5 \mathrm{~mm}$ & $0.7-0.9 \mathrm{~mm}$ & $0.9-1 \mathrm{~mm}$ \\
\hline $\begin{array}{l}\text { Distance of sorus to } \\
\text { midrib }\end{array}$ & $1-2 \mathrm{~mm}$ & Unknown & Approximately $0.5 \mathrm{~mm}$ \\
\hline Number of sporangia & $10-14$ & $6-8$ & $5-6$ \\
\hline Spores & Unknown & See Givulescu and Popa 1998 & Unknown \\
\hline
\end{tabular}

Large-scale formation of thick coal layers is often used as an indicator of moist climates in the Late Triassic and the Early-Middle Jurassic (Vakhrameev 1991). Ferns usually grew in comparatively warm and moist environments, ranging from coal-forming marshlands to riverbanks and formed the understorey level in the Jurassic palaeoforest vegetation (Van Konijnenburg-van Cittert 2002).

The Hojedk Formation yields a large number of fern taxa: Matoniaceae (Phlebopteris dunkeri, P. woodwardii and P. polypodioides), Marattiaceae (Marattiopsis munsteri), Osmundaceae (Todites williamsonii), Dipteridaceae (Clathropteris obovata and Dictyophyllum sp.), Schizaeaceae (Klukia exilis and K. westii) and Dicksoniaceae (Coniopteris hymenophylloides, Dicksonia mariopteris, Ferizianopteris undulata), Incertae sedis (Cladophlebis denticulata, Spiropteris sp.) accompanied by Equisetaceae (Annulariopsis simpsonii, Equisetites lateralis), Cupressaceae (Elatocladus laxus), Caytoniales, Bennettitales, Cycadales and Podozamitaceae.
Matoniaceae occured during the Late Triassic (i.e. Phlebopteris without indusium), but during the Jurassic forms with a well-developed indusium emerged in different genera, as in the living genus Matonia (Van Konijnenburg-van Cittert 2002). Extant Marattialean ferns are mostly restricted to lagoons (Kerp 2000; Petrescu and Codrea 2004) but the environment of members of the Mesozoic Matoniaceae can be entirely different: some of them have certainly grown under humid condition as understorey flora or along riverbanks (e.g., Selenocarpus muenstrianus, Phlebopteris polypodioides, $P$. tracyi, P. angustiloba) (Ash 1991; Philippe et al. 1998). Others have lived in stress-adapted environments (e.g., Van Konijnenburg-van Cittert and Van der Burgh 1996). One of the most impressive examples in this respect is Phlebopteris woodwardii which may be a constituent of peat forming vegetation, growing along riverbanks or inland heaths, occasionally experiencing fires (Van Konijnenburg-van Cittert 2002). Another species of 
Phlebopteris frequently preserved as fusain is $P$. dunkeri (Harris 1961; Van Konijnenburg-van Cittert 2002). Some members of this family, existing in the Cretaceous, were adapted to arid climates (Van Konijnenburg-van Cittert 2002). Dipteridaceae resemble Matoniaceae in frond branching pattern and probably climatic preferences (Van Konijnenburg-van Cittert 2002). These families have mainly lived under moist conditions in the temperate-warm and subtropical zone (Vakhrameev 1991). The first appearance of Dicksoniaceae is in the Late Triassic and the family is relatively diverse in the Jurassic and the Early Cretaceous (Van Konijnenburg-van Cittert 2002). Extant genera of this family are living in tropical and temperate rain forests on the Southern Hemisphere (Vakhrameev 1991). According to the plants identified from the Hojedk Formation and their inferred palaeoecology and also the presence of coal-bearing layers, it seems that the Hojedk Formation was deposited under a relatively warm and humid climate. This agrees with previous interpretations based on plant macro-remains from this formation (e.g., Ameri et al. 2014).

\section{Conclusions}

Although many palaeobotanists have studied the Triassic-Jurassic sedimentary successions of Iran, it was possible to provide the first evidence for two fossil taxa from the Middle Jurassic Hojedk Formation of the Tabas Block (Central Iran). Impression/compression specimens could be assigned to Phlebopteris dunkeri (Schenk) Schenk 1875 and P. woodwardii Leckenby 1864, belonging to Matoniaceae, on the basis of the morphological characters. Ecology comparison of the Hojedk Formation plant fossils with their living relatives supports deposition of the host strata under a moist warm (tropical to subtropical regime) climate during the Middle Jurassic.

\section{Additional file}

Additional file 1: Table S2. Comparison between the species of Phlebopteris (modified after Givulescu and Popa 1998). (DOCX 30 kb)

\section{Acknowledgements}

This work would not have been possible without the co-operation of the National Iranian Steel Company. We would like to extend thanks to M. S. Fakhr for his guidance and help in identification of our macro-plant fossils. We are especially indebted to F. Hashemi Yazdi and A. Dehbozorgi, who have been supportive of the career goals of the first author and who worked actively in the field. Furthermore, we thank Johanna Van Konijnenburg-van Cittert, Mihai Popa and an anonymous reviewer for their comments that helped to improve the manuscript considerably.

\section{Authors' contributions}

Both authors read and approved the final manuscript.

\section{Competing interests}

The authors declare that they have no competing interests.

\section{Publisher's Note}

Springer Nature remains neutral with regard to jurisdictional claims in published maps and institutional affiliations.

\section{Author details}

${ }^{1}$ School of Geology, Faculty of Science, University of Tehran, Tehran, Iran. ${ }^{2}$ Senckenberg Forschungsinstitut und Naturmuseum Frankfurt, Senckenberganlage 25, 60325 Frankfurt am Main, Germany.

Received: 13 March 2018 Accepted: 27 August 2018

Published online: 08 January 2019

\section{References}

Alavi, M., and G. Barale. 1970. Étude preliminaire de la flore de la Formation de Shemshak dans la region de Djam (Iran). Bulletin mensuel de la Société linnéenne de Lyon 39 (8): 241-252.

Ameri, H., M. Dastanpour, H. Khalilizade, and F. Zamani. 2014. Plant fossil remains from the Bajocian-Bathonian of Hojedk formation, Babhutk area, Kerman, Iran. Arabian Journal of Geosciences 7 (6): 2293-2302.

Arjang, B. 1975. Die räto-jurassischen Floren des Iran und Afghanistans. 1. Die Mikroflora der räto-jurassischen Ablagerungen des Kermaner Beckens (Zentral-Iran). Palaeontographica Abteilung B 152: 85-148.

Ash, S. 1991. A new Jurassic Phlebopteris (Plantae, Filicales) from the Wallowa terrane in the Snake River canyon, Oregon and Idaho. Journal of Paleontology 65: 322-329.

Barnard, P.D.W. 1967a. Flora of the Shemshak formation. Part 1. Liassic plants from Dorud. Rivista Italiana di Plaleontologia e Stratigrafia 71: 1123-1168.

Barnard, P.D.W. 1967b. Flora of the Shemshak formation. Part 2. Liassic plants from Shemshak and Ashtar. Rivista Italiana di Plaleontologia e Stratigrafia 73: 539-589.

Barnard, P.D.W. 1968. A new species of Masculostrobus Seward producing Classopollis pollen from the Jurassic of Iran. Botanical Journal of the Linnean Society 61 (384): 167-176.

Barnard, P.D.W., and J.C. Miller. 1976. Flora of the Shemshak formation (Elburz, Iran), part 3: Middle Jurassic (Dogger) plants from Katumbargah, Vasek Gah and Imam Manak. Palaeontographica Abteilung B 153: 1-117.

Boersma, M., and J.H.A. Van Konijnenburg-van Cittert. 1991. Late Triassic plant megafossils from Aghdarband (NE-Iran). Abhandlungen der Geologischen Bundesanstalt 38: 223-252.

Boureau, É., R. Furon, and L.F. Rosset. 1950. Contribution à l'étude des flores jurassiques d'Asie. Memoires du Muséum National d'Histoire Naturelle 30 (2): 207-242.

Brongniart, A. 1836. Histoire des végétaux fossiles, ou recherches botaniques et géologiques (Vol. 1). Masson.

Cleal, C.J., and P.M. Rees. 2003. The middle Jurassic flora from Stonesfield, Oxfordshire, UK. Palaeontology 46 (4): 739-801.

Corsin, P., and G. Stampfli. 1977. La Formation de Shemshak dans L'elburz Oriental (Iran) Flore-Stratigraphie-Paléogéographie. Geobios 10 (4): 509571

Fakhr, M.S. 1975. Contribution a l'étude de la flore Rhéto-Liasique de la formation de Shemshak de l'Elbourz (Iran). These Uni. Pierre et Marie Curie Paris 6; Publication du Laboratoire de Paleobotanique de l'Universite Paris 6 (2): 421.

Fürsich, F.T., M. Wilmsen, K. Seyed-Emami, and M.R. Majidifard. 2009. The midCimmerian tectonic event (Bajocian) in the Alborz Mountains, northern Iran: Evidence of the break-up unconformity of the South Caspian Basin. Geological Society, London, Special Publications 312 (1): 189-203.

Givulescu, R., and M. Popa. 1998. Aninopteris Formosa Givulescu et Popa, gen. Et sp. nov., a new Liassic matoniaceous genus and species from Anina, Banat, Romania. Review of Palaeobotany and Palynology 104 (1): 51-66.

Göppert, H.R. 1861. On the occurrence of Liassic plants in the Caucasus and in the Albours (Elbrus) Range (Persia) and on the distribution of the Liassic flora. Quarterly Journal of the Geological Society 18: 17-20.

Harris, T.M. 1961. Yorkshire Jurassic flora. In I: Thallophyta - Pteridophyta. British: Museum (Natural History).

Hirmer, M., and L. Hörhammer. 1936. Morphologie, systematik und geographische verbreitung der fossilen und rezenten Matoniaceen. Palaeontographica Abteilung B 81: 1-70.

Kerp, H. 2000. The modernization of landscapes during the late Paleozoic-early Mesozoic. The Paleontological Society Papers 6: 79-114. 
Kilpper, K. 1964. Über die Rät/Lias-Flora aus dem nördlichen Abfall des AlbursGebirges in Nordiran. Teil 1: Bryophyta und Pteridophyta. Palaeontographica Abteilung B 141: 1-78.

Kilpper, K. 1968. Einige Bennettiteen-Blätter aus dem Lias von Karmozd-Zirab (NIran). Botanical Journal of the Linnean Society 61 (384): 129-135.

Kilpper, K. 1975. Paläobotanische untersuchungen in Nord-Iran. I. Nachweis nichtmariner obertrias am nordabfall des alburs-gebirges. 1. Grossform der pflanzenfunde von seltenen gattungen. Review of Palaeobotany and Palynology 19 (2): 139-153.

Krasser, F. 1891. Über die fossile Flora der rhätischen Schichten Persiens. Sitzungsberichte der österreichischen Akademie der Wissenschaften, mathematisch-naturwissenschaftliche Klasse 100: 413-432.

Kustatscher, E., G.G. Scanu, J. Kvacek, and J.H.A. van Cittert. 2016. The Krasser collection in the Faculty of Sciences, Charles University, Prague: New insights into the middle Jurassic flora of Sardinia. Fossil Imprint 72 (3-4): 140-154.

Leckenby, J. 1864. On the sandstones and shales of the oolites of Scarborough, with descriptions of some new species of fossil plants. Quarterly Journal of the Geological Society 20 (1-2): 74-82.

Lorenz, C. 1964. Die Geologie der Oberen Karadj Thales (Zentral Elburz), Iran. Mitt Geol Inst E T H Univ 22: 1-133

Mirzaei-Ataabadi, M., M. Djafarian, and J. Mohammadalizadeh. 2005. Occurrence of Aninopteris (Matoniaceae) from the middle Jurassic of east Central Iran. Paleobotanist 54: 99-106.

Petrescu, I., and V.L.A.D. Codrea. 2004. The signification of the Paleocene microflora from Jibou (Sălaj District) for the Paleogene palinological heritage of Romania. Acta Palaeontologica Romaniae 4: 351-360.

Philippe, M., F. Thevenard, G. Barale, S. Ferry, and G. Guignard. 1998. Middle Bathonian floras and phytocoenoses of France. Palaeogeography, Palaeoclimatology, Palaeoecology 143: 135-158.

Poole, I., and M.M. Mirzaei-Ataabadi. 2005. Conifer woods of the middle Jurassic Hojedk formation (Kerman basin) Central Iran. IAWA Journal 26 (4): 489-505.

Popa, M. 1997. Liassic ferns from the Steierdorf formation, Anina, Romania. In Proceedings 4th European Palaeobotanical and Palynological conference. Meded. Nederl. Inst. Toegep. Geowetens. TNO, vol. 58, 139-148.

Popa, M.E., M. Javidan, and M. Falahatgar. 2012. Klukia exilis (Phillips 1829) Raciborski 1890 emend. Harris 1961 from Ahan Sar. Shemshak group, Iran. Acta Palaeontologica Romaniae 8 (1-2): 33-41.

Popa, M.E., and J.H.A. Van Konijnenburg-van Cittert. 1999. Aspects of Romanian early Jurassic palaeobotany and palynology. Part I. In Situ spores from the Getic nappe, Banat, Romania. Acta Palaeobotanica Romaniae, vol. 2, 181-195.

Presl, G.B. 1838. Versuch einer geognostisch-botanischen Darstellung der Flora der Vorwelt. Vol. 8, 71. Leipzig.

Saadat-Nejad, J., A. Ghaderi, and N. Ghasabian. 2010. Study of macroplant fossils of Garakhk-Shandiz region, northeast of Iran. Sedimentary Facies 2: 173-203.

Sadovnikov, G.N. 1976. The Mesozoic flora of Alborz Central Iran and its stratigraphy Importance, 118. N.I.S.C.

Sadovnikov, G.N. 1989. Taeniopteris, Nilssoniopteris, and Nilssonia in the late Triassic flora of Iran. Paleontological Journal 23: 95-100

Schenk, A. 1871. Beiträge zur Flora der Vorwelt, IV. Die Flora der nordwestdeutschen Wealdenformation. Palaeontographica 19: 201-276.

Schenk, A. 1875. Beiträge zur Flora der Vorwelt, V. Zur Flora der nordwestdeutschen Wealdenformation. Palaeontographica 23: 157-163.

Schenk, A. 1887. Fossile Pflanzen aus der Albourskette. Biblioth. Bot. Wiesbaden 6 $1-12$.

Schweitzer, H.J. 1977. Die räto-jurassischen Floren des Iran und Afghanistans. 4 Die rätische Zwitterblüte Irania hermaphroditica nov. spec. und ihre Bedeutung für die Phylogenie der Angiospermen. Palaeontographica Abteilung B 154: 98-145.

Schweitzer, H.J. 1978. Die räto-jurassischen Floren des Iran und Afghanistans. 5. Todites princeps, Thaumatopteris brauniana und Phlebopteris polypodioides. Palaeontographica Abteilung B 155: 17-60.

Schweitzer, H.J., and M. Kirchner. 1995. Die rhäto-jurassischen Floren des Iran und Afghanistans: 8. Ginkophyta. Palaeontographica Abteilung B 237: 1-58.

Schweitzer, H.J., and M. Kirchner. 1996. Die rhäto-jurassischen Floren des Iran und Afghanistans: 9. Coniferophyta. Palaeontographica Abteilung B 238: 77-139.

Schweitzer, H.J., and M. Kirchner. 1998. Die rhäto-jurassischen Floren des Iran und Afghanistans: 11. Pteridospermophyta und Cycadophyta I. Cycadales. Palaeontographica Abteilung B 248: 1-85.

Schweitzer, H.J., and M. Kirchner. 2003. Die rhäto-jurassischen Floren des Iran und Afghanistans: 13. Cycydophyta III. Bennettitales. Palaeontographica Abteilung B 264: 1-166.
Schweitzer, H.J., M. Kirchner, and J.H.A. Van Konijnenburg-van Cittert. 2000. The Rhaeto-Jurassic flora of Iran and Afghanistan. 12. Cyadophyta II. Nilssoniales. Palaeontographica Abteilung B 254: 1-63.

Schweitzer, H.J., U. Schweitzer, M. Kirchner, J.H.A. Van Konijnenburg-van Cittert, J. van der Burgh, and R.A. Ashraf. 2009. The Rhaeto-Jurassic flora of Iran and Afghanistan. 14. Pterophyta-Leptosporangiatae. Palaeontographica Abteilung B 279: 1-108.

Schweitzer, H.J., J.H.A. Van Konijnenburg-van Cittert, and J. van der Burgh. 1997. The Rhaeto-Jurassic flora of Iran and Afghanistan. 10. Bryophyta, Lycophyta, Sphenophyta, Pterophyta-Eusporangiatae and-Protoleptosporangiatae Palaeontographica Abteilung B 243: 103-192.

Seward, A.C. 1900. Catalogue of the Mesozoic Plants in the Department of Geology, British Museum (Natural History). Vol. 1. Part III-IV The Jurassic Flora The Trustees

Seyed-Emami, K. F.T. Fürsich, M. Wilmsen, G. Schairer, and M.R. Majidifard. 2004 First record of Jurassic (Toarcian-Bajocian) ammonites from the northern Lut block, east-Central Iran. Acta Geologica Polonica 54 (1): 77-94.

Stur, D. 1886. Vorlage der von Dr. Wähner aus Persien mitgebrachten fossilen Pflanzen. Verhandlungen der kaiserlich-königlichen geologischen Reichsanstalt 16: 431-436.

Vaez-Javadi, F., and M. Mirzaei-Ataabadi. 2006. Jurassic plant macrofossils from the Hojedk formation, Kerman area, east-Central Iran. Alcheringa 30 (1): 63-96.

Vakhrameev, V.A. 1991. Jurassic and cretaceous floras and climates of the earth, 318. Cambridge: Cambridge University Press.

Van der Burgh, J., and J.H.A. Van Konijnenburg-van Cittert. 1984. A drifted flora from the Kimmeridgian (upper Jurassic) of Lothbeg point, Sutherland, Scotland. Review of Palaeobotany and Palynology 43 (4): 359-396.

Van Konijnenburg-van Cittert, J.H.A. 1993. A review of the Matoniaceae based on in situ spores. Review of Palaeobotany and Palynology 78 (3-4): 235-267.

Van Konijnenburg-van Cittert, J.H.A. 2002. Ecology of some late Triassic to early cretaceous ferns in Eurasia. Review of Palaeobotany and Palynology 119 (1-2): 113-124.

Van Konijnenburg-van Cittert, J.H.A., and J. Van der Burgh. 1996. Review of the Kimmeridgian flora of Sutherland, Scotland, with reference to the ecology and in situ pollen and spores. Proceedings of the Geologists' Association 107: 97- 105.

Vassiliev, Y. 1984. Mesozoic plant fossils from coal areas in Iran. VII. 97. Atlas of the Ministry of Mines and Metals 2 (2): 47.

Zeiller, R. 1905. Sur les plantes rhétiennes de la Perse recueillies par MJ de Morgan. Société géologique de France 5: 190-198.

\section{Submit your manuscript to a SpringerOpen ${ }^{\circ}$ journal and benefit from:}

- Convenient online submission

- Rigorous peer review

- Open access: articles freely available online

- High visibility within the field

- Retaining the copyright to your article

Submit your next manuscript at $>$ springeropen.com 